Article

\title{
Social Investment Policies in the EU: Actively Concrete or Passively Abstract?
}

\author{
Gaby Umbach and Igor Tkalec* \\ Robert Schuman Centre for Advanced Studies, European University Institute, Italy; E-Mails: gaby.umbach@eui.eu (G.U.), \\ igor.tkalec@eui.eu (I.T.) \\ * Corresponding author
}

Submitted: 28 January 2021 | Accepted: 23 March 2021 | Published: 25 June 2021

\begin{abstract}
Against the historical-conceptual background of EU social policy and evolutionary governance, this article analyses the approach with which the EU propagates social investment policies. Social investment, understood as an active rather than passive way of social protection, has become a salient instrument for reinvigorating the EU's social dimension, especially in the aftermath of the sovereign debt crisis. By means of a large-scale document analysis, we develop four EU social investment propagation approaches (reference, objective, tool, and action) according to how active (passive) and concrete (abstract) the EU's intervention in social investment is. The results show that the EU mainly propagates social investment with an active approach, i.e., policy recommendations targeted at national governments. In terms of substance, the EU's treatment of social investment is based on labour activation policies backed by skills development and job search support policies, which is consistent with the main purpose of social investment.
\end{abstract}

\section{Keywords}

co-evolutionary governance; EU social policy; labour market activation; social investment

\section{Issue}

This article is part of the issue "Steering in Governance: Evolutionary Perspectives" edited by Kristof Van Assche (University of Alberta, Canada / University of Bonn, Germany) and Raoul Beunen (Open University, The Netherlands).

(C) 2021 by the authors; licensee Cogitatio (Lisbon, Portugal). This article is licensed under a Creative Commons Attribution 4.0 International License (CC BY).

\section{Introduction}

In January 2021, the Portuguese Presidency of the Council of the European Union and EU Commission President Ursula von der Leyen scheduled the 2021 tripartite EU Social Summit. As von der Leyen underlined, the summit needed to particularly address the younger generation with a focus on solidarity. Concretely, it should "focus on how to strengthen Europe's social dimension to meet the challenges of climate change and the digital transition, in order to ensure equal opportunities for all and that no one is left behind" (European Commission, 2021, p. 1). The summit should therefore enhance support for the EU's social dimension with the general objective of improving people's wellbeing to add to the recovery path from the hardship of the Covid-19 pandemic. This summit's mission is in line with the March 2021 Commission communication on the European Pillar of the Social Rights Action Plan, which aims to reinvigorate the EU's social dimension (see European Commission, 2021). The need to improve the implementation of the European Pillar of Social Rights (EPSR) shows that the EU has not yet realised the commitments made at its adoption in 2017.

This article addresses this inertia concerning social issues as compared to macro-economic policies and reforms (Graziano \& Hartlapp, 2018; Moreno and Palier speak of a "European social model... a kaleidoscope of sediments and peculiarities" [Moreno \& Palier, 2005, p. 2]). It asks how, if at all, the EU can deliver on its bold promises. It starts with the question of whether the EU's socio-economic co-evolutionary governance 
armoury offers enough steering potential to turn its EPSR commitments into reality. To operationalise this question, we focus on the propagation of social investment by the EU in its policy documents and activities across different levels of governance as a way to address social concerns. The main idea of social investment is that "social policy should no longer focus on 'passively' protecting people from the perils of the market by means of cash benefits, but rather prepare or 'empower' people in order to maximally integrate them into the market" (Jenson \& Saint-Martin as cited in Cantillon \& Van Lancker, 2013, p. 553). Social investment has been well-developed in the academic literature, notably from the theoretical-conceptual (Hemerijck, 2015; Kvist, 2015), critical (Cantillon \& Van Lancker, 2013) and (national) case study (Bouget et al., 2015; Cantillon, 2011; Jenson \& Saint-Martin, 2003) perspectives. In the EU context, Vandenbroucke et al. (2011) discuss the need for a social investment pact.

Building on the above, this article offers an empirical analysis exclusively from the EU perspective. The main objective is to analyse the ways in which the EU propagates social investment policies. To this end, we define four propagation approaches, depending on whether they actively discuss and promote social investment and whether they involve concrete EU intervention in social investment (see Figure 1). The reference and objective approaches relate to the paradigmatic dimension of the EU's treatment of social investment, while the tool and action approaches refer to the level of intervention. The propagation approaches are inspired by the conceptual framing of social investment put forward by Bouget et al. (2015) in their analysis of national social investment policy practices. In the context of the present analysis, conceptual framing concerns which policy fields and sub-fields are integral components of social investment.

The remainder of this article is organised as follows. We first discuss the development of EU social policy governance and its co-evolutionary patterns across governance levels. We then focus on the role of social investment in the EU especially in the aftermath of the sovereign debt crisis. Subsequently, we describe our methodological approach based on the analysis of textual data. Finally, we present the results of the analysis, focusing on the EU's social investment propagation approaches.

\section{EU Social Policy Governance}

In terms of the EU's steering potential, political steering theory (Börzel, 2005, p. 617; Burth \& Görlitz, 2001; Mayntz, 1987, 2003; Mayntz \& Scharpf, 1995), multilevel governance approaches (Héritier, 2002; Hix, 1998; Hooghe \& Marks, 2001; Kohler-Koch, 2003; Marks et al., 1996; Peters, 2002; Sandholtz \& Stone Sweet, 1998; Umbach, 2017; Wallace, 2005) and Evolutionary Governance Theory in particular (Beunen et al., 2016; Van Assche et al., 2014; Yagi, 2020) inform us that multilevel governance arrangements involve co-evolution across levels of governance-vertically (supranational, national, regional, local) and horizontally (various actors, including markets, institutions, and civil society). Such multilevel co-evolutionary governance and steering logics-ranging from regulatory (state) intervention in political coordination and negotiation systems to competition mechanisms and self-regulation-are particularly relevant to EU social policy.

EU social policy is therefore an exemplary field of governance co-evolution across systemic levels given that
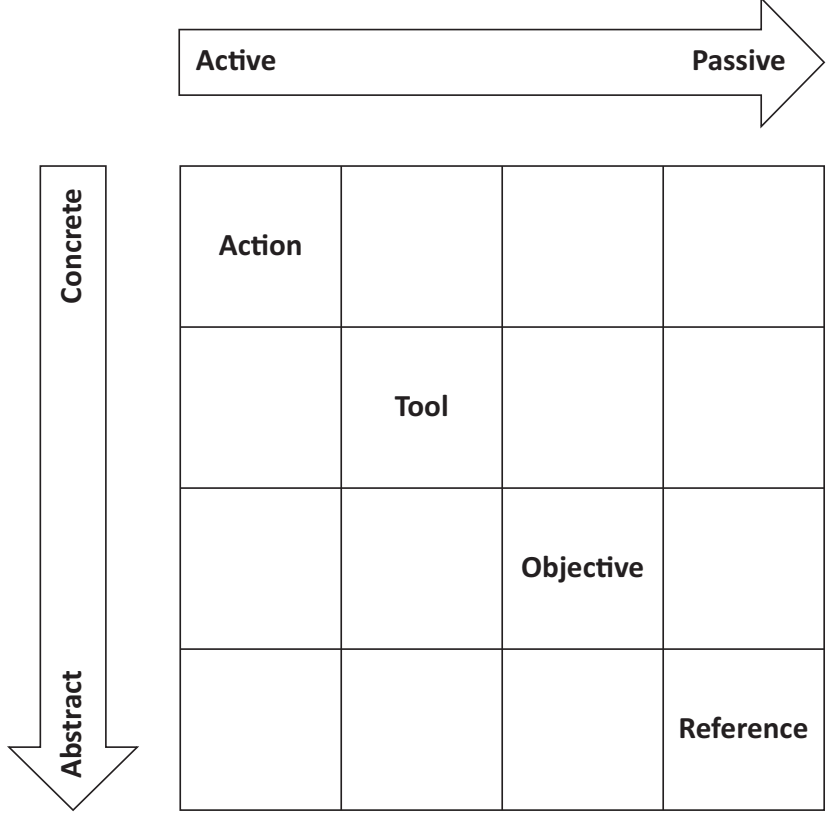

Figure 1. The EU's social investment propagation approaches. 
its progress is based not only on vertical cooperation between the EU level and member states but also on horizontal cooperation among individuals, markets, and the public sector. In legal terms, Arts. 2 and 3 in the Treaty on European Union (TEU) define different social dimensions of the EU's multilevel political system (prominently equal rights and non-discrimination; the social market economy; economic, social, and territorial cohesion; social justice; social protection, and solidarity; TEU, 2012). Titles IX, X, XI, XII, XIV, and XVIII in the Treaty on the Functioning of the European Union (TFEU) specify EU social policy areas (TFEU, 2012). This multi-faceted social fabric is reflected in the multilevel governance patterns of EU social policy. As Art. 4 in the TFEU states, social policy predominantly resides in the realm of shared competences (TFEU, 2012). This means that both the EU and its member states can adopt legislation. EU member states legislate where the EU does not exercise its competences. Art. 6 in the TFEU locates questions of protection and improvement of human health, education, and vocational training in the realm of supporting competences, in which the EU is limited to complementary action while EU member states legislate (TFEU 2012). This combination of legal competences impacts on how EU social policies are co-designed and it reflects the fact that no exclusive legal authority has been transferred to the EU. This constitutes the starting point for the governance co-evolution arena at hand and impacts on how EU social policies are made within the EU's multilevel system. From a governance perspective, EU social policy is steered by various policy instruments, depending on the legal basis applied and ranging from regulatory approaches to policy coordination. This variety of governance modes materialises the multilevel steering patterns of the EU's social dimension (Scharpf, 2002) and further strengthens the co-evolutionary governance potential in the area.

The development of EU social policy over time explains the multidimensionality of its legal and governance basis. Defined as a matter of national sovereignty with limited room for manoeuvre for the European Economic Community in the Treaty of Rome, social policy remained shaped by national policy priorities and regimes with a noticeable opposition to further Europeanisation. Liberal, conservative, and social democratic welfare regimes continued to co-exist and two approaches to EU social policy emerged: the (neo)liberal idea of 'Market Europe' with little room for European social policy; and the 'Social Europe' approach aiming at further communitarisation beyond the European Social Fund, common vocational training policies, and equal pay provisions. A lack of consensus and concern about negative repercussions of social integration on the economic development of the Community prevailed, hampering the development of a European social policy (Dodo, 2014). As a result, coherence is missing in EU socio-economic policies as "European integration has created a constitutional asymmetry between policies promoting market efficiencies and policies promoting social protection and equality" (Scharpf, 2002, p. 646).

A fundamental moment for the definition of social rights at the EU level was the 2000 Charter of Fundamental Rights of the European Union (European Parliament et al., 2012). This unites different layers of individual rights (human, economic, civic, and social) that EU citizens are subject to in the EU. Again, a result of governance co-evolution in the area, the sources of this basic rights catalogue are dispersed across different levels of governance (European Convention on Human Rights, constitutional provisions of EU member states, international instruments, and the case law of the Court of Justice of the EU). Another relevant step in EU social policy development was the 2017 Gothenburg Social Summit. The summit inter-institutionally proclaimed the EPSR, which defines three target areas for socially sustainable labour markets (equal opportunities and access; fair working conditions; and social protection and inclusion; European Parliament et al., 2018). Legal competences for achieving the EPSR targets, however, again remain divided. The member states are legally empowered to design governance solutions, whereas the EU is attributed a supporting action role. Moreover, in 2019 the Commission reinstated the EU social pillar in its policy guidelines, highlighting the need to "reconcile the social and the market" and to "put forward an action plan to fully implement the European Pillar of Social Rights" (von der Leyen, 2019, p. 9). In this climate of sluggish but necessary implementation of the EPSR, the EU's social agenda requires reanimation in 2021, not least because of the impact of the Covid-19 pandemic. In sum, the development of EU social policy can be encompassed under a slow and lagging "governance path" (Van Assche et al., 2014, p. 29).

\section{The EU Social Investment Approach}

On this slow 'governance path,' the 2007/2008 financial and economic and the 2010-2012 sovereign debt crises increased the pressure on both EU member states and the EU level to become bolder on the social dimension of European integration. The crises "reinforce[d] the need to modernise social policies to optimise their effectiveness and efficiency, and the way they are financed" (European Commission, 2013, p. 2). To this end, in 2013 the Commission defined the cornerstones of social investment in its communication on Social Investment for Growth and Cohesion (see European Commission, 2013). Linked to the Europe 2020 Strategy for smart, sustainable and inclusive growth, the Commission stated that social investment policies, combined with protection and stabilisation as functions of welfare regimes, were essential welfare state instruments to increase the effectiveness and efficiency of social policies (European Commission, 2013).

A series of documents attached to the Commission's communication form the 'Social Investment Package' 
(SIP), which should redirect "Member States' policies, where needed, towards social investment throughout life, with a view to ensuring the adequacy and sustainability of budgets for social policies and for the government and private sector as a whole" (European Commission, 2013, p. 3). As a supranational stimulus, the SIP has had governance consequences at the $\mathrm{EU}$ and national levels, requiring interlinkage among social policies, the European Semester, the EU's Employment Package, pensions coordination, cohesion policies, and EU funding policies. As such, it inspired and required the European Semester's co-evolutionary governance process to adapt in terms of framing of policy paradigms (i.e., reference and objective propagation approaches) and intervention types (i.e., tool and action propagation approaches).

As a result, the EU's social investment approach created vertical and horizontal adaptation stimuli for EU member states and across the different levels of the EU system. Borrowing from the Europeanisation literature, such stimuli can stem from various co-evolution dynamics between levels of governance: down-loading and adaptation of national governance by transfer of European provisions (top-down Europeanisation); up-loading and establishment of European governance (bottom-up Europeanisation); and cross-loading and transfer of governance approaches between national and subnational levels based on EU stimuli (vertical transfer; Howell, 2004a, pp. 5-6, 2004b, pp. 54-56). Feedback loops between the different dynamics accompany coevolutionary governance developments (Bomberg \& Peterson, 2000, p. 20; Börzel, 2003; Börzel \& Risse, 2000, pp. 1-2, 2003, p. 57; Giuliani, 2003, p. 135; Olsen, 2002, p. 932; Radaelli, 2003, p. 30) as this "pattern of couplings between systems creates a space for change and for possible intervention" (Van Assche et al., 2014, p. 19; see Beunen \& Van Assche, 2013). For our analysis, stimuli deriving from top-down dynamics seem particularly relevant as they highlight inspiration for adaptation through EU level reference points, policy paradigms and intervention types.

Against this historical-conceptual backdrop, this article focuses on how, when and in what form the EU propagates social investment, creating stimuli and reference points for other levels of governance through top-down dynamics. The in what form aspect constitutes the nucleus of our analysis and evolves around the categorisation of social investment policies (in terms of flow, stock, and buffer characteristics; see Table 1). By choosing this perspective, we focus on the treatment of contemporary social investment at the EU level as a potential way of instigating co-evolutionary governance dynamics in policy areas that do not fall under the exclusive competence of the EU. To this end, we understand social investment as a mode of aligning national policies with the EU's governance approach in its post-sovereign debt crisis policy agenda and its 2020 strategy.

\section{Data and Method}

We use document analysis as the main method. The analysis involves manual coding of documents and quantitative interpretation of textual data. Our sample consists of 293 EU documents from the period from 2010 to 2020 (except for the EU Charter of Fundamental Rights from 2000). The selection of EU document types is based on their potential relevance regarding social investment policies (see Appendix 1 in the Supplementary File). The documents refer to social investment within the notions of policy development (e.g., the Commission's White Papers), policy objectives (e.g., Annual Growth Surveys), and policy recommendations (e.g., CountrySpecific Recommendations [CSRs]).

The main unit of analysis is the (grammatical) sentence. Sentences in the selected documents that mention social investment policies (see Table 1) are coded in terms of: a) the specific policy field they refer to (e.g., upskilling, unemployment benefits); b) the social investment policy category (flow, stock, or buffer); and c) the EU propagation approach. It should be noted that the three social investment policy categories (flow, stock, and buffer) indicate which policy sub-fields are considered in the analysis. Nevertheless, they also inform social investment from a policy implementation standpoint. Concretely, an effective social investment strategy ought

Table 1. Social investment policy categories.

\begin{tabular}{|c|c|c|c|}
\hline Category & Flow (labour market) & Stock & Buffer \\
\hline Specific policy field & $\begin{array}{l}\text { - Participation } \\
\text { - Activation } \\
\text { - Access } \\
\text { - Flexibility } \\
\text { - Flexicurity } \\
\text { - Life-course transitions } \\
\text { - Relevance of skills }\end{array}$ & $\begin{array}{l}\text { - Human capital } \\
\text { - Education } \\
\text { - Upskilling } \\
\text { - Vocational training } \\
\text { - Lifelong learning } \\
\text { - Gender equality } \\
\text { - R\&D } \\
\text { - Childhood care }\end{array}$ & $\begin{array}{l}\text { - Health } \\
\text { - Unemployment benefits } \\
\text { - Career support } \\
\text { - Job search assistance } \\
\text { - Social housing } \\
\text { - Minimum income support }\end{array}$ \\
\hline
\end{tabular}

Note: Due to our efforts to reflect the content of the raw data (i.e., sentences) as closely as possible, the number and labels of specific policy fields used in the analysis slightly differ from those listed in the table (cf. Figure 4). Source: Authors' adaption from Bouget et al. (2015). 
to combine and integrate policy interventions from all three categories. The interventions need to consider a life course perspective as social investment entails a continuum of measures rather than one-off and/or ad-hoc policy actions. Moreover, the interventions need to be mutually reinforcing to account for the different objectives of different social policy categories (Bouget et al., 2015). To illustrate, changes in unemployment benefit schemes (buffer) bolster incentives for labour market participation (flow). The cost of such intervention can be mediated by, for instance, re-qualification opportunities (stock). From this demand for mutual reinforcement also follows the relevance of vertical coevolutionary governance in the implementation of social investment policies.

In our text analysis, a single sentence can be coded multiple times (i.e., if it mentions manifold social investment policies and/or entails multiple EU propagation approaches). A total of 2068 coded segments are included in the analysis. While coding the sentences, in addition to their meaning, we consider specific word types and/or specific words that help indicate to which propagation approach the coded segments belong (see Appendix 2 in the Supplementary File).

EU social investment propagation approaches reflect the EU's framing and treatment of social investment in its documents. Specifically, four propagation approaches reflect: a) how active (or passive) the EU is in proposing and promoting social investment policies; and b) the level of concreteness of the EU's intervention in social investment (see Figure 1). The reference approach concerns mere mentioning and/or factual description of social investment policies in EU documents. As such, it is passive and abstract. The objective approach includes propagation of social investment policies as a desirable policy aim/objective, incentivising social investment policies and placing social investment on policy and political agendas in EU politics. Therefore, it is more active and concrete than the reference approach. The tool approach understands social investment policies as policy tools that help achieve another policy objective, which may or may not be related to social investment. It is therefore both active and concrete in terms of the EU's propagation of social investment. Finally, the action approach includes the EU's recommendations for policy actions regarding social investment. The policy action is directly targeted at national governments. Therefore, it is the most active and concrete propagation approach.

Broadly speaking, we expect the reference and objective approaches to be relatively less prominent. The momentum of the reference approach may have decreased due to the overall development of the supranational social policy armoury since the early 2000 s (e.g., European Employment Strategy; the open method of coordination). Concerning the objective approach, the legal basis of EU social policy (shared competences in many and supporting competences in some areas) discussed above makes it potentially less attractive for the
EU given that the normative (steering) intensity of defining policy aims and objectives is not negligible. Hence, we expect tool and action approaches to be more prominent as they reflect the main mission of the European Semester policy coordination cycle and its increased relevance to the social policy realm. The Semester involves monitoring and recommendation practices in order to foster policy reforms at the national level (i.e., the action approach) and, to a lesser degree, it offers the means to achieve such reforms (i.e., the tool approach).

\section{Results and Discussion}

We focus on three aspects of the analysis which provide insights into how, when and in what form the EU propagates social investment. First, the how aspect directly concerns the EU propagation approaches. As Figure 2 shows, the EU propagates social investment predominantly through action (recommending policy actions to member states) and tool (utilising specific social investment policies as a means to achieve social investment or other policy goals) approaches. Therefore, the EU's treatment of social investment is active and concrete. As such, it institutionally directly targets national governments. Hence, it could be argued that active propagation of social investment is well-integrated in the EU's social investment policy narrative expressed in its policy documents.

The second aspect of the analysis concerns the temporal dimension (the when) of the EU's propagation of social investment. As Figure 3 shows, there is no evident linear trend in terms of use of the four propagation approaches from 2010 to 2020 . The use of the action approach steadily increases from 2011 and peaks in 2014. This is followed by a decline from 2015 to 2020. The use of the objective approach is relatively constant over the entire time period. This also holds for the tool approach, yet with an obvious decline in 2020. The reference approach was used more frequently from 2010 to 2013, whereas from 2013 to 2020 use of it was relatively negligible with the exceptions of 2016 and 2017.

The temporal aspect of the analysis implies that social investment persistently appears as an integral policy objective and a tool to achieve other (non-)related policy objectives at the EU level. Although the action approach is most frequently employed (see Figure 2), from a temporal perspective its use by the EU is somewhat periodical. References to the action approach predominantly derive from CSRs. Considering this, a significant decline in use of the action approach in 2015 coincides with the introduction of the streamlined European Semester, under which recommendations have become simpler, shorter, and fewer (Alcidi \& Gros, 2017). Hence, explicit references to social investment may have been 'absorbed' by other more targeted policy recommendations, potentially signalling a shift of supranational steering to these tools. Moreover, this 


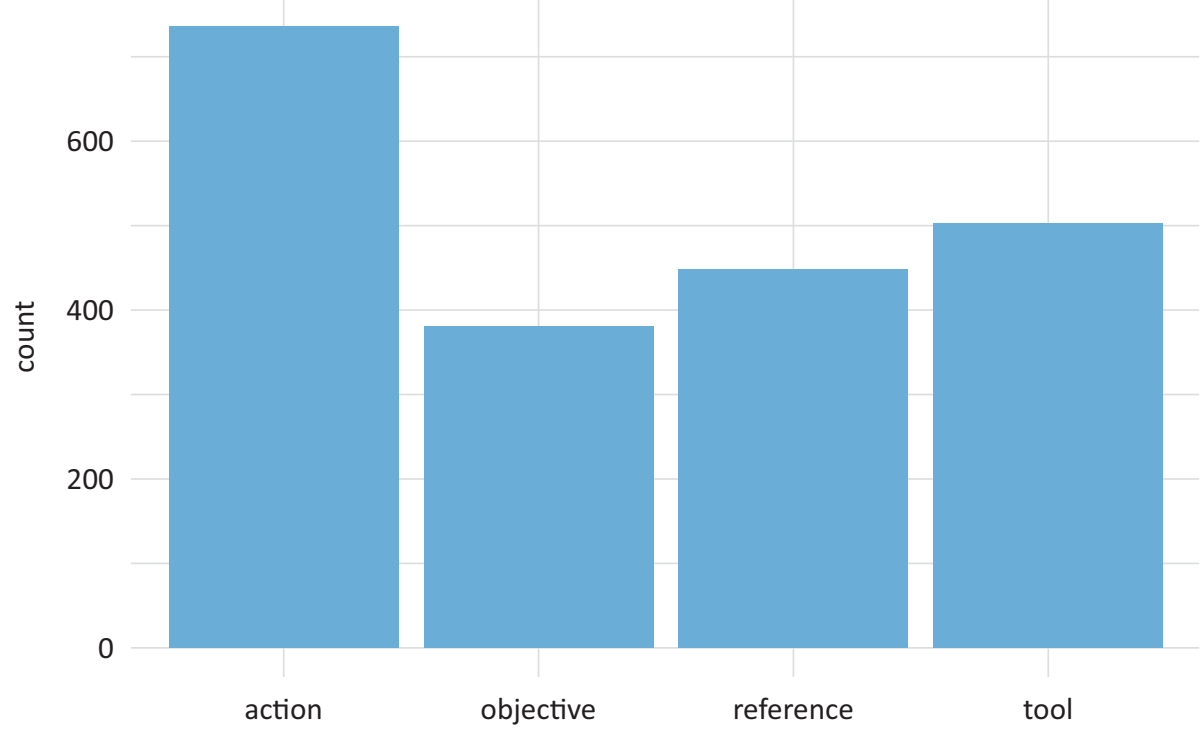

Figure 2. Occurrence frequency of EU social investment propagation approaches.

decline may have occurred due to a successful implementation of social investment-related policy recommendations at the national level. Nevertheless, the present analysis cannot support such claims as it does not consider changes in CSRs content and their implementation at the national level. Therefore, and due to the secondary importance of the when aspect of the analysis, we do not elaborate further on this.

Finally, the in what form aspect is the core of our analysis. It concerns categories of social investment policies (flow, stock, and buffer; see Table 1) and their specific policy fields. Put differently, it unfolds the substance of the EU's social investment propagation approaches. As such, it underlines the characteristics of social investment in the EU. Policies in the stock category are prevalent with a particular emphasis on skills (e.g., upskilling, addressing skills mismatches) and training-related (e.g., vocational training, lifelong learning) policies. Enhancing (labour market) skills is predominantly propagated as a policy objective (see Figure 4 , row 4 , column 2), while, correspondingly, training-related policies mainly serve as policy tools (see Figure 4, row 4, column 4). Therefore, from the EU perspective, professional development appears as a prominent channel for using social investment. Interestingly, human capital and gender equality are relatively underrepresented in the EU documents and are mostly propagated through the descriptive reference propagation approach.

Policies in the flow category exclusively concern the labour market. Labour market activation policies appear most often in the documents (see Figure 4, row 1, column 1). From a broader economic perspective, relatively frequent references to the flexibility (including flexicurity; see Bekker, 2018) of labour markets (see Figure 4, row 2, column 1) feed into the prominence of activation policies. Activation-focused policies-reducing disincentives to work (Raffass, 2017) and encouraging individuals to search for employment aiming at a re-entry in employment (after the initial encounter with unemployment)-are pervasively communicated

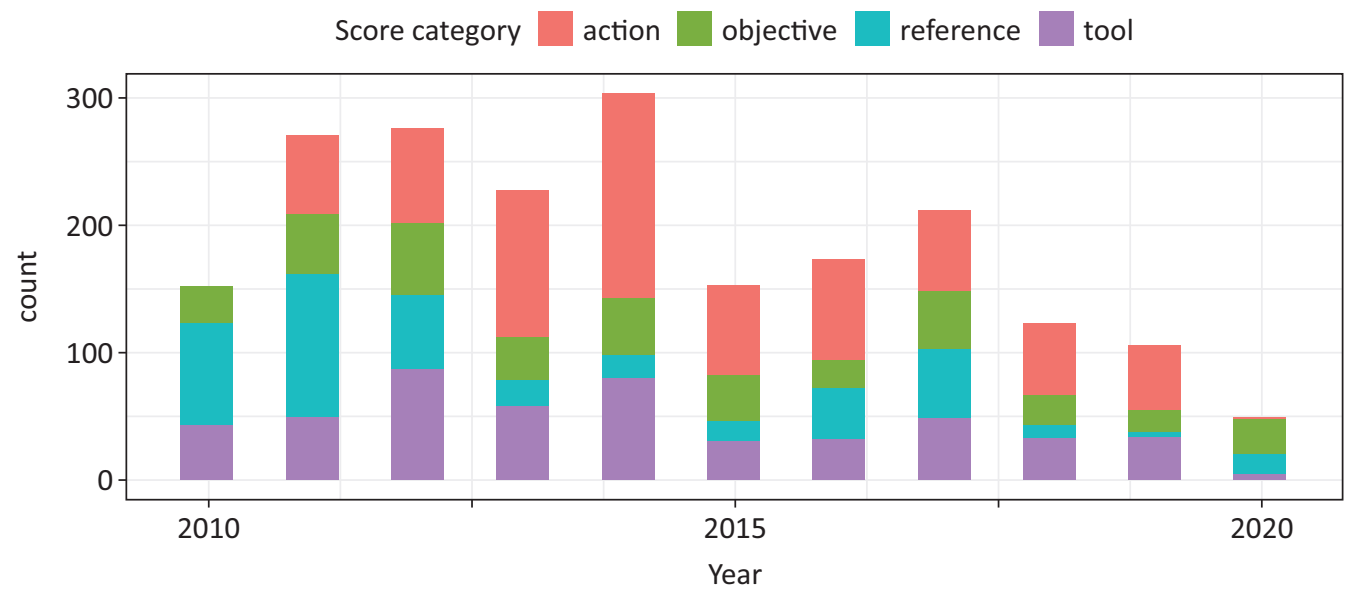

Figure 3. Occurrence frequency of the EU's propagation approaches over time. 


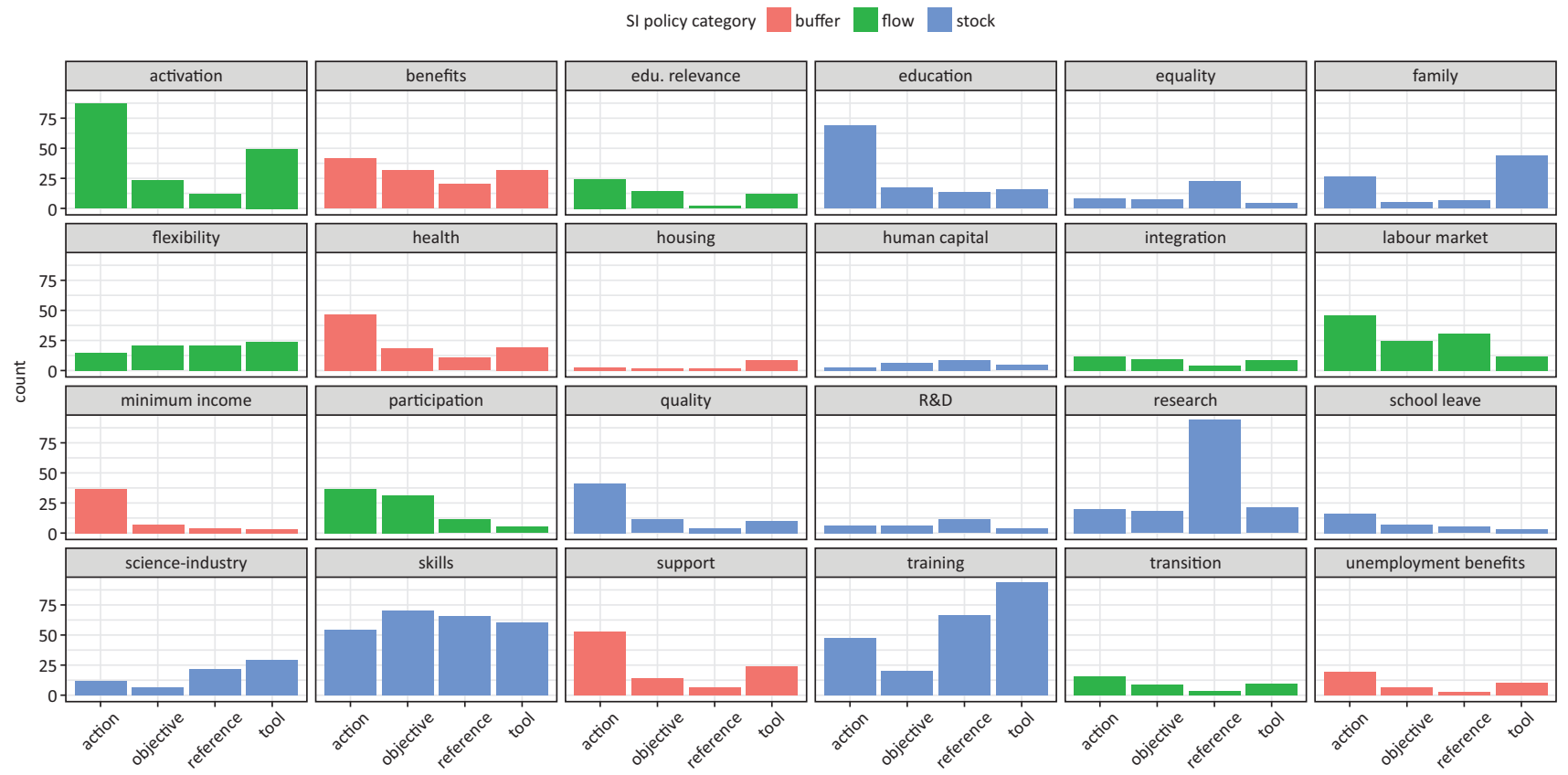

Figure 4. Distribution of the EU's propagation approaches across social investment policies. Note: education, labour market, and benefits policies are generic and encompassing in nature due to difficulties or inability to specify a policy field in some coded segments.

through active and concrete social investment propagation approaches (i.e., tool and action).

The treatment of unemployment benefit policies by the EU in the flow category complements the prominent role of activation policies. Mentioning of unemployment benefits appears relatively less frequently in the EU documents and is mostly communicated through the action propagation approach (see Figure 4, row 5, column 6). This means that the EU (in annual CSRs) recommends policy action to governments concerning their unemployment benefit schemes. Some unemployment benefit-focused policy recommendations entail reducing their duration and generosity. For example, in 2015 the EU recommended that the French government should "[t]ake action in consultation with the social partners and in accordance with national practices to reform the unemployment benefit system in order to bring the system back to budgetary sustainability and provide more incentives to return to work" (Council of the EU, 2015, p. 7). Such policy recommendations complement and reinforce the main aim of the prevalent references to activation policies.

Insights from the other two categories of social investment also build on the salience of activation policies. In the stock category, although relatively underrepresented, family policies (e.g., improving childcare services) are among the main policy tools (see Figure 4, row 1 , column 6) to achieve activation. References to family policies mainly highlight the need to enable (equal) female labour market participation after childbirth. For example, the 2019 Annual Growth Surveys states that "[w]ider access to high-quality care services (e.g., childcare and long-term care) would ensure more opportunities for women to enter or stay in employment" (European Commission, 2018, p. 12). In terms of policy recommendations, the EU recommended Austria, for instance, to "[i]mprove labour market outcomes for women also through the provision of full-time care services" (Council of the EU, 2017, p. 6). Moreover, in 2019, Italy was recommended to “[s]upport women's participation in the labour market through a comprehensive strategy, including through access to quality childcare and long-term care" (Council of the EU, 2019, p. 12).

Policies in the buffer category are overall relatively less represented in the selected corpus of EU documents. Nevertheless, relatively frequent mentioning of (job) support policies (e.g., public employment services, efficiency and coordination of job centres, individual career counselling) through action and tool approaches strengthens the general emphasis on activation policies (see Figure 4, row 4, column 3). In this context, support policies act as an intermediate step between unemployment and re-entering employment. To this end, from a broader perspective, the Commission states that "[p]ublic employment services and sectoral organisations also play an important role in retraining workers who have to change occupation or sector, thus facilitating reallocation of labour between firms and sectors" (European Commission, 2012, p. 16). Concerning related policy recommendations, the EU recommended to "[e]valuate the effectiveness of the public employment service, notably on career guidance and counselling services, to improve the matching of skills with labour market needs" (CSR 2011 for Slovenia; Council of the EU, 2011, p. 6). Therefore, job support systems have the potential to enable smoother implementation 
of labour market activation policies (see Black et al., 2003; Heidenreich \& Aurich-Beerheide, 2014). Table 2 summarises the main findings of the document analysis.

Overall, the dominant policy themes through which the EU propagates social investment are enhancing the labour market and education skills (stock), labour market activation policies (flow), and job support policies (buffer). These themes are complementary and interconnected. Their interaction reflects a dynamic treatment of contemporary social investment at the EU level. Enhanced labour market and education skills enable more efficient implementation of labour market activation policies as skilled individuals are seemingly more competitive and have a higher capacity to adjust to labour market demands. Therefore, they are more likely to switch from unemployment to re-employment in a timely manner, which is the overarching aim of activation policies. In this context, job support policies underpin skills development through, for example, statesponsored professional (i.e., re-qualification) or soft skill training and/or individual career counselling that aims to make the job search a confidence-boosting experience. Moreover, job support policies reinforce activation policies (assuming they are effective) as they reduce the cost of and demand for unemployment benefits.

In sum, regarding the above-discussed coevolutionary governance and adaptation stimuli, contemporary social investment in the EU broadly reflects top-down dynamics in so far as the EU uses an active approach to foster reforms at the national level. The core idea is to stimulate national governance adaptation through recommendations that create a supranational reference point for policy change. Our findings largely support this as the EU mainly treats social investment through the action propagation approach, which entails direct policy recommendations to national governments and it is consistent with the idea of 'governance by objectives' (see Vandenbroucke et al., 2011). Moreover, social investment based on activation policies reflects the existing division of competences between the $\mathrm{EU}$ and its member states concerning social policy as broadly understood and fits into the EU's post sovereign debt crisis and Europe 2020 Strategy policy agenda with competitive and knowledge-based economies as overarching goals. It is also consistent with its main purpose to 'transform' welfare provision from the passive collection of benefits (protection from the market) into active participation in and adjustment to the labour market.
However, one should be wary of the broader implications of activation-centred social investment. First, studies on activation policies contend that they are conducive to socio-economic policy outcomes such as decreasing poverty levels and unemployment, and social inclusion (see, e.g., Perkins, 2010; Raffass, 2017). Second, such apparent incompatibility between economic and social policies also concerns EU economic governance under the European Semester, in which social concerns are subjugated to their economic counterparts (see Bekker, 2015; Spasova et al., 2019; Zeitlin \& Vanhercke, 2018). Therefore, the EU's commitment to traditional social policy outcomes appears feeble. Consequently, social investment as a novel instrument for social policy may be undermined, considering that it "cannot and will not ensure social progress for all if it is not complemented by a firm commitment to traditional forms of social protection" (Cantillon \& Van Lancker, 2013, p. 561). In other words, governance co-evolution for social progress derives from a complementarity of (activation-centred) social investment and traditional welfare provision. The EU has been somewhat engaged with the former yet (still) lags with the latter, which remains a competence of EU member states.

\section{Conclusion}

Against the historical-conceptual background of EU social policy and Evolutionary Governance Theory, we have analysed the ways in which the EU propagates social investment, using large-scale document analysis as the research method. The results show that active propagation of social investment is well-integrated in the EU's social investment policy space. Using a well-established instrument of EU economic and social policy coordination, the EU propagates social investment mainly through active and concrete approaches communicated through annual CSRs to national governments, which confirms our initial expectations. This propagation approach hence adds to the EU's socio-economic co-evolutionary governance armoury of the European Semester to contribute to the implementation of the EPSR. The EU's treatment of social investment is based on active labour market policies backed by skills development and job support policies, echoing 'Market Europe' ideas, the Europe 2020 Strategy's focus on a knowledge-based competitive economy, and the European Employment Strategy's focus on increased employability and adaptability (Umbach,

Table 2. Summary of the main findings of the document analysis.

\begin{tabular}{lll}
\hline Social investment policy category & Dominant specific policy field(s) & Salient EU propagation approach \\
\hline FLOW & Labour market activation & Tool; Action \\
STOCK & Skills & Objective \\
& Training (vocational and lifelong) & Tool \\
BUFFER & Job support & Tool; Action \\
\hline
\end{tabular}


2009, pp. 196-198). In terms of co-evolutionary governance, this treatment of social investment points to the use of top-down stimuli by the EU. Activation-centred social investment is consistent with its inherent purpose, yet it alone may not prove effective enough to substantively advance 'Social Europe,' considering the 'tension' between economic and social policy priorities and outcomes in EU governance.

Although our analysis is empirically compelling, it has limitations. Concretely, it does not consider the national level, which is crucial for the implementation of social investment policies on EU recommendations, and, more importantly, it does not discuss potential socioeconomic effects of the dominant policy themes in the EU's treatment of social investment. Nevertheless, the analysis offers an empirical validation of the definition of social investment in the EU context, which constitutes one of the article's main contributions. In addition, the findings of the analysis give insights into the EU's role in social policy, which historically has a strong national character. The fact that the EU's treatment of social investment is active and concrete potentially indicates an increased role of the EU in the social field. The EU's increasingly important role in social investment unravels through policy coordination under the European Semester, the latter itself a governance mode of aligning member states' policies with the EU's governance approach that instigates co-evolutionary governance dynamics in EU socio-economic policies. Such developments have already occurred in other areas of social policy, including pensions (see, e.g., Guardiancich \& Guidi, 2020; Tkalec, 2020). Moreover, from a practical point of view and in the context of existing studies on social investment, an exclusive empirical focus on the EU level and (reusable) operationalisation of large-scale textual data are the article's further contributions to deepen the understanding of social investment in the EU context.

From the theoretical perspectives of Europeanisation and multilevel governance, this article may add to the long-present notion of national de-structuring without supranational re-construction (Ferrera, 2005), which depicts the EU's role in social policy. In the current EU multilevel governance context, national de-structuring unwinds through down-loading and the top-down dynamics of the European Semester, which has embraced social policy issues and has enabled a more prominent role for the EU in social affairs. Active and concrete propagation of social investment by the EU exemplifies such a development also in areas that do not fall under the exclusive competence of the EU. Nevertheless, (positive) integration towards a more 'Social Europe' through up-loading and bottom-up dynamics in social affairs has remained somewhat minor. The EPSR signalled a positive move in this respect, but, as we noted in the introduction, the EU has not yet fully realised its commitments under the Pillar. In other words, social investment to some extent potentially entails a 'Europeanised' dimension achieved 'through the back door' of economic and fiscal policy coordination under the European Semester. However, it is vital to emphasise that our analysis does not directly imply this; it instead offers a descriptive framework that can serve as a starting point for unravelling such arguments further. To this end, causal relationships concerning the magnitude of pressure exerted by the EU on national governments in terms of social investment ought to be contemplated in future research efforts. Such analyses have the capacity to empirically demonstrate the plausibility and validity of such arguments. In our future research, we aim to focus on social investment at the national level and the role of the EU in it.

\section{Conflict of Interests}

The authors declare no conflict of interests.

\section{Supplementary Material}

Supplementary material for this article is available online in the format provided by the authors (unedited).

\section{References}

Alcidi, C., \& Gros, D. (2017). How to strengthen the European Semester? (CEPS Research Report No. 2017/15). Centre for European Policy Studies.

Bekker, S. (2015). European socioeconomic governance in action: Coordinating social policies in the third European Semester (1) (OSE Research Paper No. 19). L'Observatoire Social Européen.

Bekker, S. (2018). Flexicurity in the European Semester: Still a relevant policy concept? Journal of European Public Policy, 25(2), 175-192. https://doi.org/ 10.1080/13501763.2017.1363272

Beunen, R., \& Van Assche, K. (2013). Contested delineations: Planning, law and the governance of protected areas. Environment and Planning A, 45(6), 1285-1301.

Beunen, R., Van Assche, K., \& Duineveld, M. (2016). Evolutionary governance theory. Springer.

Black, D. A., Smith, J. A., Berger, M. C., \& Noel, B. J. (2003). Is the threat of reemployment services more effective than the services themselves? Evidence from random assignment in the UI System. American Economic Review, 93(4), 1313-1327. https://doi.org/ $10.1257 / 000282803769206313$

Bomberg, E., \& Peterson, J. (2000). Policy transfer and Europeanization: Passing the Heineken test? Queen's University Belfast.

Börzel, T. A. (2003). Shaping and taking EU policies: Member State responses to Europeanization (Queen's Papers on Europeanisation Working Paper No. 1/2003). Queens' University Belfast. https:// www.researchgate.net/publication/5015726_ Shaping_and_Taking_EU_Policies_Member_State_ Responses_to_Europeanization 
Börzel, T. A. (2005). European governance: Markt, Hierarchie oder Netzwerk? [European governance: Market, hierarchy or network?]. In G. F. Schuppert, I. Pernice, \& U. Haltern (Eds.), Europawissenschaft [European studies] (pp. 613-641). Nomos.

Börzel, T. A., \& Risse, T. (2000). When Europe hits home: Europeanization and domestic change. European Integration Online Papers (EloP), 4(15). http:// dx.doi.org/10.2139/ssrn.302768

Bouget, D., Frazer, H., Merlier, E., Sabato, S., \& Vanhercke, B. (2015). Social investment in Europe: A study of national policies. European Commission, DirectorateGeneral for Employment, Social Affairs and Inclusion.

Burth, H.-P., \& Görlitz, A. (Eds.). (2001). Politische Steuerung in Theorie und Praxis: Baden-Baden [Political steering in theory and practice]. Nomos.

Cantillon, B. (2011). The paradox of the social investment state: Growth, employment and poverty in the Lisbon era. Journal of European Social Policy, 21(5), 432-449. https://doi.org/10.1177/0958928711418856

Cantillon, B., \& Van Lancker, W. (2013). Three shortcomings of the Social Investment Perspective. Social Policy and Society, 12(4), 553-564. https://doi.org/ $10.1017 / \mathrm{S} 1474746413000080$

Council of the EU. (2011). Council recommendation of 12 July 2011 on the National Reform Programme 2011 of Slovenia and delivering a Council opinion on the updated Stability Programme of Slovenia, 2011-2014 (No. 2011/C 217/01). Council of the European Union.

Council of the EU. (2015). Council recommendation of 14 July 2015 on the 2015 National Reform Programme of France and delivering a Council opinion on the 2015 Stability Programme of France (No. 2015/C 272/14). Council of the European Union.

Council of the EU. (2017). Council recommendation of 11 July 2017 on the 2017 National Reform Programme of Austria and delivering a Council opinion on the 2017 Stability Programme of Austria (No. 2017/C 261/19). Council of the European Union.

Council of the EU. (2019). Council recommendation of 9 July 2019 on the 2019 National Reform Programme of Italy and delivering a Council opinion on the 2019 Stability Programme of Italy (No. 2019/C 301/12). Council of the European Union.

Dodo, M. K. (2014). Historical evolution of the social dimension of the European integration: Issues and future prospects of the European social model. L'Europe en Formation, 2(372), 51-66.

European Commission. (2012). GREEN PAPER Restructuring and anticipation of change: What lessons from recent experience? (No. SEC[2012] 59). European Commission.

European Commission. (2013). Towards social investment for growth and cohesion-Including implementing the European Social Fund 2014-2020 (COM[2013] 83 final). European Commission. http:// ec.europa.eu/social/BlobServlet?docld=9761 \&langld=en
European Commission. (2018). Annual growth survey 2019: For a stronger Europe in the face of global uncertainty (COM[2018] 770). European Commission.

European Commission. (2021, January 15). Commission and Portuguese Presidency announce Social Summit in Porto [Press release]. European Commission. https://ec.europa.eu/commission/presscorner/ detail/en/ip_21_101

European Parliament, Council of the EU, \& European Commission. (2012). Charter of fundamental rights of the European Union (Official Journal of the European Union C 326/391). https://eur-lex.europa.eu/ legal-content/EN/TXT/PDF/?uri=CELEX:12012P/TXT\& from $=\mathrm{EN}$

European Parliament, Council of the EU, \& European Commission. (2018). European pillar of social rights. Publications Office of the EU.

Ferrera, M. (2005). The boundaries of welfare: European integration and the new spatial politics of social protection. Oxford University Press.

Giuliani, M. (2003). Europeanization in comparative perspective: Institutional fit and national adaptation. In K. Featherstone \& C. M. Radaelli (Eds.), The politics of Europeanization (pp. 134-155). Oxford University Press.

Graziano, P., \& Hartlapp, M. (2018). The end of social Europe? Understanding EU social policy change. Journal of European Public Policy, 26(10), 1484-1501.

Guardiancich, I., \& Guidi, M. (2020). The political economy of pension reforms in Europe under financial stress. Socio-Economic Review, mwaa012. https:// doi.org/10.1093/ser/mwaa012

Heidenreich, M., \& Aurich-Beerheide, P. (2014). European worlds of inclusive activation: The organisational challenges of coordinated service provision. International Journal of Social Welfare, 23(S1), S6-S22. https://doi.org/10.1111/ijsw.12098

Hemerijck, A. (2015). The quiet paradigm revolution of social investment. Social Politics: International Studies in Gender, State \& Society, 22(2), 242-256. https://doi.org/10.1093/sp/jxv009

Héritier, A. (Ed.). (2002). Common goods: Reinventing European and international governance. Rowman \& Littlefield.

Hix, S. (1998). The study of the European Union II: The 'new governance' agenda and its rival. Journal of European Public Policy, 5(1), 38-65. https://doi.org/ 10.1080/13501768880000031

Hooghe, L., \& Marks, G. (2001). Multi-level governance and European Integration. Rowman \& Littlefield.

Howell, K. E. (2004a). Developing conceptualisations of Europeanization: Synthesising methodological approaches (Queen's Papers on Europeanization, No. 3/2004). Queen's University Belfast. https:// ideas.repec.org/p/erp/queens/p0044.html

Howell, K. E. (2004b). Uploading, downloading and European integration: Assessing the Europeanisation of 
UK financial services regulation. Journal of International Banking Regulations, 6(1), 53-68.

Jenson, J., \& Saint-Martin, D. (2003). New routes to social cohesion? Citizenship and the social investment state. Canadian Journal of Sociology/Cahiers Canadiens de Sociologie, 28(1), 77-99. https://doi. org/10.2307/3341876

Kohler-Koch, B. (Ed.). (2003). Linking EU and national governance. Oxford University Press.

Kvist, J. (2015). A framework for social investment strategies: Integrating generational, life course and gender perspectives in the EU social investment strategy. Comparative European Politics, 13(1), 131-149. https://doi.org/10.1057/cep.2014.45

Marks, G., Hooghe, L., \& Blank, K. (1996). European Integration from the 1980s: State-centric v. Multilevel Governance. Journal of Common Market Studies, 34(3), 341-378.

Mayntz, R. (1987). Politische Steuerung und gesellschaftliche Steuerungsprobleme-Anmerkungen zu einem theoretischen Paradigma [Political steering and issues in societal steering-Remarks on a theoretical paradigm]. In

T. Ellwein, D. Grimm, J. J. Hesse, \& G. F. Schuppert (Eds.), Jahrbuch zur Staats-und Verwaltungswissenschaft [Yearbook of political and administrative science] (Vol. 1, pp. 89-110). Nomos.

Mayntz, R. (2003, September 7-11). From government to governance: Political steering in modern societies [Paper presentation]. International Summer Academy "From Government to Governance: The case of Integrated Product Policy," Würzburg, Germany.

Mayntz, R., \& Scharpf, F. W. (Eds.). (1995). Gesellschaftliche Selbstregelung und politische Steuerung [Societal self-regulation and political steering]. Campus.

Moreno, L., \& Palier, B. (2005). The Europeanisation of welfare: Paradigm shifts and social policy reforms. In P. Taylor-Gooby (Ed.), Ideas and welfare state reform in Western Europe (pp. 145-175). Palgrave MacMillan.

Olsen, J. P. (2002). The many faces of Europeanization. Journal of Common Market Studies, 40(5), 921-952. https://doi.org/10.1111/1468-5965.00403

Perkins, D. (2010). Activation and social inclusion: Challenges and possibilities. Australian Journal of Social Issues, 45(2), 267-287.

Peters, G. B. (2002). Governance: A garbage can perspective (Working Paper No. 84). Institute for Advanced Studies. http://aei.pitt.edu/347

Radaelli, C. M. (2003). The Europeanisation of public policy. In K. Featherstone \& C. M. Radaelli (Eds.), The politics of Europeanization (pp. 27-56). Oxford University Press.

Raffass, T. (2017). Demanding activation. Journal of
Social Policy, 46(2), 349-365. https://doi.org/ 10.1017/S004727941600057X

Sandholtz, W., \& Stone Sweet, A. (Eds.). (1998). European integration and supranational governance. Oxford University Press.

Scharpf, F. W. (2002). The European social model. Journal of Common Market Studies, 40(4), 645-670.

Spasova, S., Louvaris Fasois, C., \& Vanhercke, B. (2019). Pension reforms after the crisis: Bringing adequacy back in the domestic and EU policy equation? In N. da Costa Cabral \& N. Cunha Rodrigues (Eds.), The future of pension plans in the EU internal market (pp. 283-310). Springer. https://doi.org/10.1007/978-3030-29497-7_16

Tkalec, I. (2020). Shaping the prospects for adequate pensions: The effect of policy guidelines under the European Semester. Political Research Exchange, 2(1), 1738898. https://doi.org/10.1080/2474736X. 2020.1738898

Treaty on European Union, Consolidated Version (C 326/15), 2012.

Treaty on the Functioning of the European Union, Consolidated Version (C 326/47), 2012.

Umbach, G. (2009). Intent and reality of the European employment strategy: Europeanisation of national employment policies and policy-making? Nomos.

Umbach, G. (2017). Measuring (global) governance: The potential, the practical, and the problematic assessment of governance within and beyond the state. In A. Triandafyllidou (Ed.), Global governance from regional perspectives: A critical view (pp. 45-69). Oxford University Press.

Van Assche, K., Beunen, R., \& Duineveld, M. (2014). Evolutionary governance theory: An introduction. Springer.

Vandenbroucke, F., Hemerijck, A., \& Palier, B. (2011). The EU needs a social investment pact (OSE Paper Series, Opinion Paper No. 5, May 2011). European Social Observatory.

von der Leyen, U. (2019). A Union that strives for more: My agenda for Europe. European Commission. https://ec.europa.eu/info/sites/info/files/politicalguidelines-next-commission_en_0.pdf

Wallace, W. (2005). Post-sovereign governance: The EU as a partial polity. In H. Wallace, W. Wallace, \& M. A. Pollack (Eds.), Policy-making in the European Union (5th ed., pp. 483-503). Oxford University Press.

Yagi, K. (2020). From reproduction to evolutionary governance: Toward an evolutionary political economy. Springer.

Zeitlin, J., \& Vanhercke, B. (2018). Socializing the European Semester: EU social and economic policy coordination in crisis and beyond. Journal of European Public Policy, 25(2), 149-174. https://doi.org/ 10.1080/13501763.2017.1363269 


\section{About the Authors}

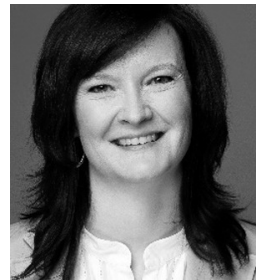

Gaby Umbach is Part-time Professor and GlobalStat Director at the Robert Schuman Centre for Advanced Studies (EUI). She is non-resident Visiting Fellow of the European Parliamentary Research Service, Adjunct Professor at the Universities of Innsbruck and LUISS Guido Carli/CIFE, Book Review Editor in the Journal of Common Market Studies, and Editorial Board Member of the International Journal Evaluation and Program Planning. Her research focuses on multilevel governance, indicatorbased politics, measuring as governance technique, and evidence-informed policy-making.

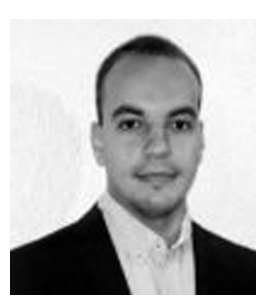

Igor Tkalec is Research Associate for the GlobalStat project at the Robert Schuman Centre for Advanced Studies of the European University Institute (EUI). He obtained his PhD in Political Science at the University of Luxembourg. His research interests focus on political economy, social policy, and data science for social research. He founded and coordinates the Applied Data Science for Social Research Working Group at the Robert Schuman Centre (EUI). 